ARTICLE

\title{
In situ tuning of electronic structure of catalysts using controllable hydrogen spillover for enhanced selectivity
}

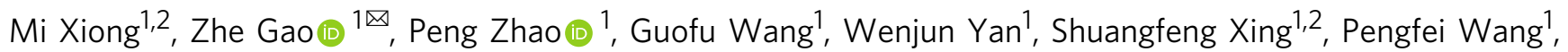
Jingyuan $\mathrm{Ma}^{3}$, Zheng Jiang (1) ${ }^{3}$, Xingchen Liu (1) ${ }^{1}$, Jiping $\mathrm{Ma}^{4}$, Jie Xu (i) ${ }^{4}$ \& Yong Qin (1) ${ }^{1,2 \times}$

In situ tuning of the electronic structure of active sites is a long-standing challenge. Herein, we propose a strategy by controlling the hydrogen spillover distance to in situ tune the electronic structure. The strategy is demonstrated to be feasible with the assistance of $\mathrm{CoO}_{x} /$ $\mathrm{Al}_{2} \mathrm{O}_{3} / \mathrm{Pt}$ catalysts prepared by atomic layer deposition in which $\mathrm{CoO}_{x}$ and $\mathrm{Pt}$ nanoparticles are separated by hollow $\mathrm{Al}_{2} \mathrm{O}_{3}$ nanotubes. The strength of hydrogen spillover from $\mathrm{Pt}$ to $\mathrm{CoO}_{x}$ can be precisely tailored by varying the $\mathrm{Al}_{2} \mathrm{O}_{3}$ thickness. Using $\mathrm{CoO}_{x} / \mathrm{Al}_{2} \mathrm{O}_{3}$ catalyzed styrene epoxidation as an example, the $\mathrm{CoO}_{x} / \mathrm{Al}_{2} \mathrm{O}_{3} / \mathrm{Pt}$ with $7 \mathrm{~nm} \mathrm{Al}_{2} \mathrm{O}_{3}$ layer exhibits greatly enhanced selectivity (from $74.3 \%$ to $94.8 \%$ ) when $\mathrm{H}_{2}$ is added. The enhanced selectivity is attributed to the introduction of controllable hydrogen spillover, resulting in the reduction of $\mathrm{CoO}_{x}$ during the reaction. Our method is also effective for the epoxidation of styrene derivatives. We anticipate this method is a general strategy for other reactions.

\footnotetext{
${ }^{1}$ State Key Laboratory of Coal Conversion, Institute of Coal Chemistry, Chinese Academy of Sciences, 030001 Taiyuan, China. ${ }^{2}$ Center of Materials Science and Optoelectronics Engineering, University of Chinese Academy of Sciences, 100049 Beijing, China. ${ }^{3}$ Shanghai Synchrotron Radiation Facility, Shanghai Institute of Applied Physics, Chinese Academy of Sciences, 201204 Shanghai, China. ${ }^{4}$ State Key Laboratory of Catalysis, Dalian National Laboratory for Clean Energy, Dalian Institute of Chemical Physics, Chinese Academy of Sciences, 116023 Dalian, China. ${ }^{凶}$ email: gaozhe@sxicc.ac.cn; qinyong@sxicc.ac.cn
} 
ighly efficient and selective catalysts are important for the industrial production of commodity chemicals, as well as fine chemicals and pharmaceuticals ${ }^{1}$. The development of new heterogeneous catalysts for carrying out multipath reactions with high selectivity to achieve high-yield production of target chemicals is a longstanding challenge $\mathrm{e}^{2,3}$. The final product distribution, i.e., the selectivity of a reaction over a given catalyst, is determined by the relative activation barrier among different reaction paths, which in nature, primarily depend on the electronic structure of the catalytic active sites ${ }^{4-6}$. However, under reaction conditions, the electronic structures of active sites are easily affected by temperature, atmosphere, and absorbed species $^{7,8}$. It is difficult to control the active sites to maintain the optimal electronic structure during the reaction, which favors producing more target products. Some researchers have devoted substantial effort to studying how to control and tune the electronic structures of the active sites responsible for activity and selectivity under real reaction conditions ${ }^{9,10}$. In contrast to numerous studies on identifying catalytically active sites under real-time reaction conditions ${ }^{11-14}$, limited methods have been reported for controlling and tuning the electronic structure of active sites during a reaction.

In general, the hydrogen migration from the metal particles to the support, i.e., hydrogen spillover, is a well-known phenomenon in heterogeneous catalysis and is involved in many important reactions ${ }^{15-24}$. The efficiency and spatial extent of hydrogen spillover strongly depend on the types of supports ${ }^{25,26}$. For instance, a well-defined model system demonstrated that on the nonreducible alumina support, hydrogen spillover is limited to short distances, with the hydrogen flux decreasing over distance to create a concentration gradient ${ }^{25}$. In-depth understanding of hydrogen spillover can not only help to explain experimental phenomena but also aid the design of advanced catalysts with enhanced catalytic performances ${ }^{27-35}$. Being inspired by these researches, we posit that there is an opportunity for an approach to modulating the electronic structure of active sites through regulating hydrogen spillover strength for enhanced catalytic performance.

In this work, using the $\mathrm{CoO}_{x}$ catalyzed epoxidation reaction of styrene as an example, we propose an approach to tune the electronic structure of cobalt species during the reaction by the introduction of controllable hydrogen spillover, to enhance the selectivity of styrene oxide (SO). To demonstrate the strategy, a $\mathrm{CoO}_{x} / \mathrm{Al}_{2} \mathrm{O}_{3} / \mathrm{Pt}$ catalyst is prepared by a facile and general template-assisted atomic layer deposition (ALD) $\operatorname{method}^{36-38}$, in which $\mathrm{CoO}_{x}$ and $\mathrm{Pt}$ nanoparticles are attached on the outer and inner surfaces of $\mathrm{Al}_{2} \mathrm{O}_{3}$ nanotubes, respectively. The strength of hydrogen spillover from $\mathrm{Pt}$ to $\mathrm{CoO}_{x}$ can be precisely tailored by varying the thickness of the $\mathrm{Al}_{2} \mathrm{O}_{3}$ layer. The $\mathrm{CoO}_{x} / \mathrm{Al}_{2} \mathrm{O}_{3} / \mathrm{Pt}$ catalyst with $7 \mathrm{~nm}$-thick $\mathrm{Al}_{2} \mathrm{O}_{3}$ layer exhibits greatly enhanced selectivity (from $74.3 \%$ to $94.8 \%$ ) when $\mathrm{H}_{2}$ atmosphere is introduced. Detailed analyses reveal that the cobalt species under the oxidation condition are reduced to a lower oxidation state by introducing the controllable hydrogen spillover, leading to a higher SO selectivity.

\section{Results}

Synthesis and characterization of the catalysts. $\mathrm{CoO}_{x} / y \mathrm{Al}_{2} \mathrm{O}_{3} / \mathrm{Pt}$ catalysts with a separating $\mathrm{Al}_{2} \mathrm{O}_{3}$ layer were obtained using carbon nanocoils (CNCs) as sacrificial templates (Supplementary Fig. 1). First, $\mathrm{Pt}$ nanoparticles and an $\mathrm{Al}_{2} \mathrm{O}_{3}$ layer were deposited onto $\mathrm{CNCs}$ by $\mathrm{Pt}$ ALD and $\mathrm{Al}_{2} \mathrm{O}_{3}$ ALD, respectively. Subsequently, the CNC templates were removed by calcination under ambient atmosphere. Finally, $\mathrm{CoO}_{x}$ nanoparticles were deposited by $\mathrm{CoO}_{x} \mathrm{ALD}$, producing $\mathrm{CoO}_{x} / y \mathrm{Al}_{2} \mathrm{O}_{3} / \mathrm{Pt}$ (where $y$ is the cycle numbers of $\mathrm{ALD} \mathrm{Al}_{2} \mathrm{O}_{3}$ ). For comparison, two reference catalysts $\left(\mathrm{CoO}_{x} / 50 \mathrm{Al}_{2} \mathrm{O}_{3}\right.$ and $\left.50 \mathrm{Al}_{2} \mathrm{O}_{3} / \mathrm{Pt}\right)$ were also synthesized by a similar method.

Figure $1 \mathrm{a}-\mathrm{c}$ present the structure diagrams of $\mathrm{CoO}_{x} / 50 \mathrm{Al}_{2} \mathrm{O}_{3}$, $\mathrm{CoO}_{x} / 50 \mathrm{Al}_{2} \mathrm{O}_{3} / \mathrm{Pt}$, and $\mathrm{CoO}_{x} / 100 \mathrm{Al}_{2} \mathrm{O}_{3} / \mathrm{Pt}$. Figure $1 \mathrm{~d}-\mathrm{f}$ show transmission electron microscopy (TEM) images of the three catalysts. TEM images of other catalysts, including $\mathrm{CoO}_{x} / y \mathrm{Al}_{2} \mathrm{O}_{3} /$ $\mathrm{Pt}$ with different cycles of $\mathrm{ALD} \mathrm{Al}_{2} \mathrm{O}_{3}(35,65,80$, and 300) and the reference catalyst $\left(50 \mathrm{Al}_{2} \mathrm{O}_{3} / \mathrm{Pt}\right)$, are shown in Supplementary Fig. 2. For all TEM images, $\mathrm{Al}_{2} \mathrm{O}_{3}$ hollow structures can be clearly observed. The $\mathrm{CoO}_{x} / y \mathrm{Al}_{2} \mathrm{O}_{3} / \mathrm{Pt}$ with different $\mathrm{Al}_{2} \mathrm{O}_{3}$ cycles (35, $50,65,80,100$, and 300) possess varied $\mathrm{Al}_{2} \mathrm{O}_{3}$ thicknesses from 5, $7,9,11,14$, to $41 \mathrm{~nm}$. Regardless of $\mathrm{Al}_{2} \mathrm{O}_{3}$ thicknesses, the outer $\mathrm{CoO}_{x}$ and the inner $\mathrm{Pt}$ nanoparticles have similar average diameters (Supplementary Figs. 3 and 4), which is consistent with $\mathrm{X}$-ray diffraction (XRD) result (Supplementary Fig. 7 and Supplementary Table 1). A high-resolution TEM (HRTEM) image of $\mathrm{CoO}_{x} / 50 \mathrm{Al}_{2} \mathrm{O}_{3} / \mathrm{Pt}$ is shown in Supplementary Fig. 5. The high-angle annular dark field scanning transmission electron microscopy (HAADF-STEM) images (Fig. 1h, i) of $\mathrm{CoO}_{x} /$ $50 \mathrm{Al}_{2} \mathrm{O}_{3} / \mathrm{Pt}$ and $\mathrm{CoO}_{x} / 100 \mathrm{Al}_{2} \mathrm{O}_{3} / \mathrm{Pt}$ clearly show that Pt nanoparticles are confined in $\mathrm{Al}_{2} \mathrm{O}_{3}$ nanotubes. Energy-dispersive $\mathrm{X}$ ray spectroscopy (EDS) mappings of the catalysts show that the distributions of $\mathrm{Co}, \mathrm{O}, \mathrm{Al}$, and $\mathrm{Pt}$ (Fig. $\mathrm{lj}$ and $\mathrm{l}$ ) are consistent with the positions of the $\mathrm{CoO}_{x}, \mathrm{Al}_{2} \mathrm{O}_{3}$, and Pt layers. Further, the distributions of $\mathrm{Co}, \mathrm{Al}$, and $\mathrm{Pt}$ in $\mathrm{CoO}_{x} / 50 \mathrm{Al}_{2} \mathrm{O}_{3} / \mathrm{Pt}$ were revealed clearly by STEM image and EDX mapping (Fig. 2a-d) of a crosssectional specimen, prepared by focused ion beam (FIB) milling along the vertical direction of the $\mathrm{Al}_{2} \mathrm{O}_{3}$ nanotubes. The linescanning profile (Fig. 2e) of cross-sectional composition shows that the signal of $\mathrm{Co}$ species was not detected in the $\mathrm{Al}_{2} \mathrm{O}_{3}$ nanotubes, which clearly demonstrates the separated structure of $\mathrm{CoO}_{x} / 50 \mathrm{Al}_{2} \mathrm{O}_{3} / \mathrm{Pt}$. The $\mathrm{Al}$ peak at $\sim 4.5 \mathrm{~nm}$ is ascribed to signal of powder (from the FIB ion milling) remained in the space nearby the outer surface of the sample (Supplementary Fig. 6). The Co and $\mathrm{Pt}$ contents in the catalysts, measured by inductively coupled plasma-atomic emission spectrometry (ICP-AES), are shown in Supplementary Table 2. $\mathrm{N}_{2}$ sorption experiments (Supplementary Fig. 8 and Supplementary Table 3) demonstrate that all the catalysts possess similar average pore diameter, while their Brunauer-Emmett-Teller (BET) surface areas and pore volumes increase with the decrease of $\mathrm{Al}_{2} \mathrm{O}_{3}$ thicknesses.

$\mathrm{X}$-ray photoelectron spectroscopy (XPS) results (Fig. 3a) reveal the coexistence of $\mathrm{Co}^{3+}$ and $\mathrm{Co}^{2+}$. Compared to the spinel $\mathrm{Co}_{3} \mathrm{O}_{4}$, the main $2 p$ peaks of $\mathrm{CoO}_{x} / 50 \mathrm{Al}_{2} \mathrm{O}_{3}, \mathrm{CoO}_{x} / 50 \mathrm{Al}_{2} \mathrm{O}_{3} / \mathrm{Pt}$, and $\mathrm{CoO}_{x} / 100 \mathrm{Al}_{2} \mathrm{O}_{3} / \mathrm{Pt}$ shift to higher binding energy (the $2 p_{3 / 2}$ peaks shift from 779.5 to $780.0 \mathrm{eV}$ and the $2 p_{1 / 2}$ peaks shift from 794.7 to $795.9 \mathrm{eV})$, and the satellite peaks appear $\left(785.6 \mathrm{eV}\left(2 p_{3 / 2}\right.\right.$ sat) and $802.3 \mathrm{eV}\left(2 p_{3 / 2}\right.$ sat $\left.)\right)$, indicating that the as-prepared $\mathrm{CoO}_{x}$ nanoparticles consist of both $\mathrm{Co}^{2+}$ and $\mathrm{Co}^{3+}$ species ${ }^{39,40}$. Hydrogen temperature-programmed reduction $\left(\mathrm{H}_{2}-\mathrm{TPR}\right)$ was also employed (Fig. 3b). Compared to $\mathrm{CoO}_{x} / 50 \mathrm{Al}_{2} \mathrm{O}_{3}$, the peak intensity of $\mathrm{CoO}_{x} / 50 \mathrm{Al}_{2} \mathrm{O}_{3} / \mathrm{Pt}$ centered at $622^{\circ} \mathrm{C}$ decreases significantly, which is because the $\mathrm{CoO}_{x}$ species can be additionally reduced by the spilled active hydrogen from $\mathrm{Pt}$ nanoparticles. The peak intensity of $\mathrm{CoO}_{x} / 100 \mathrm{Al}_{2} \mathrm{O}_{3} / \mathrm{Pt}$ centered at $626^{\circ} \mathrm{C}$ is remained, possibly because the $\mathrm{Al}_{2} \mathrm{O}_{3}$ layer of 100 ALD cycles $(14 \mathrm{~nm})$ is too thick and the hydrogen spillover effect is greatly weakened. The differences in reducibility of Co (Supplementary Table 4) demonstrate that the flux of spilled hydrogen species on the nonreducible $\mathrm{Al}_{2} \mathrm{O}_{3}$ support decreases with increasing distance.

Catalytic performance. The epoxidation of olefins is an important chemical reaction since epoxides are key intermediates in 


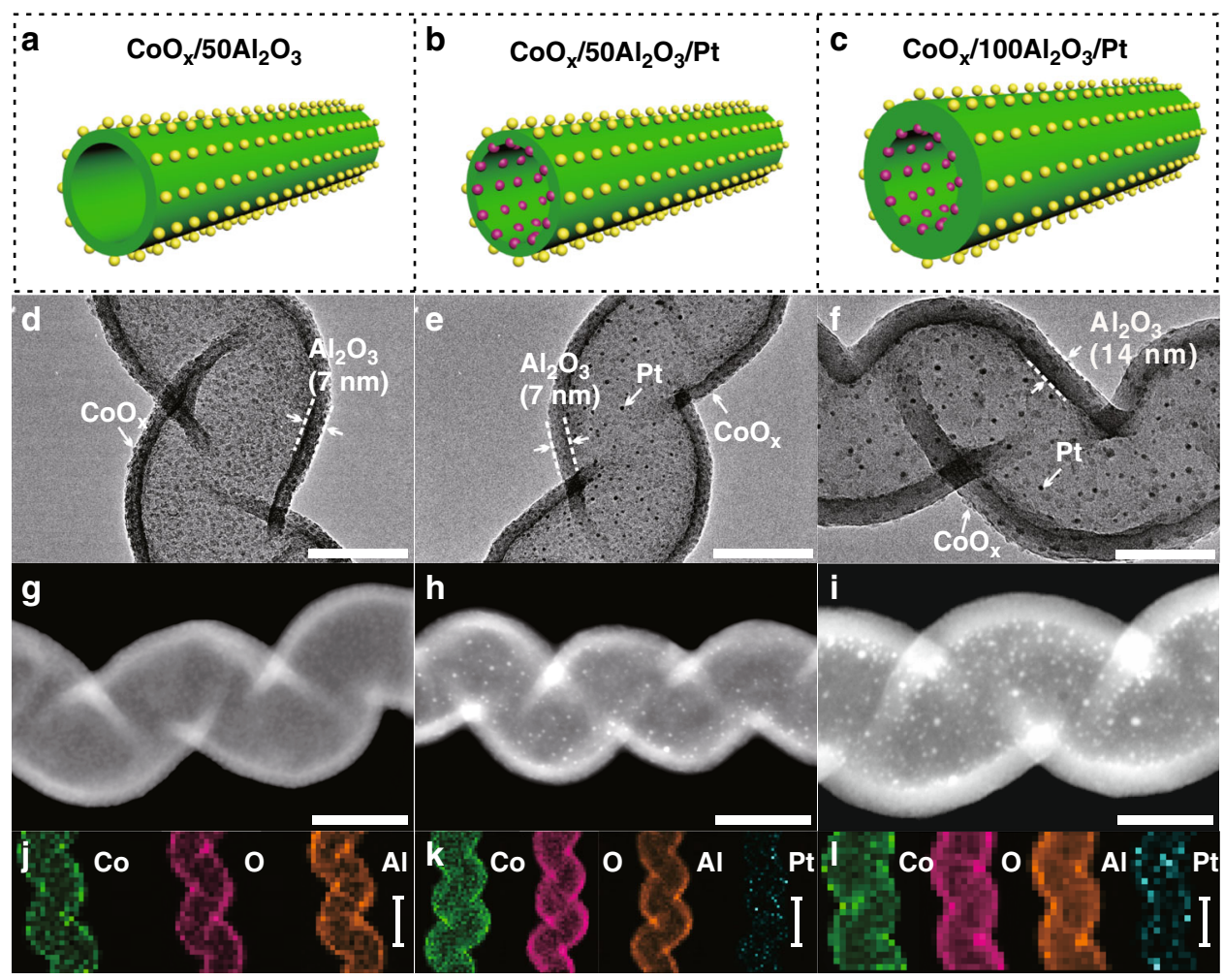

Fig. 1 Structural characterization of the catalysts. a-c Structure diagrams (The green tubes represent $\mathrm{Al}_{2} \mathrm{O}_{3}$. The magenta and yellow balls represent $\mathrm{Pt}$ and $\mathrm{CoO}_{x}$, respectively), d-f TEM images (scale bar, $50 \mathrm{~nm}$ ), g-i HAADF-STEM images (scale bar, $50 \mathrm{~nm}$ ), and $\mathbf{j}-\mathbf{I}$ EDX elemental mappings (scale bar, $100 \mathrm{~nm}$ ) of the catalysts. $\mathbf{a}, \mathbf{d}, \mathbf{g}, \mathbf{j}: \mathrm{CoO}_{x} / 50 \mathrm{Al}_{2} \mathrm{O}_{3} ; \mathbf{b}, \mathbf{e}, \mathbf{h}, \mathbf{k}: \mathrm{CoO}_{x} / 50 \mathrm{Al}_{2} \mathrm{O}_{3} / \mathrm{Pt}$; and $\mathbf{c}, \mathbf{f}, \mathbf{i}, \mathbf{I} \mathrm{CoO}_{x} / 100 \mathrm{Al}_{2} \mathrm{O}_{3} / \mathrm{Pt}$.
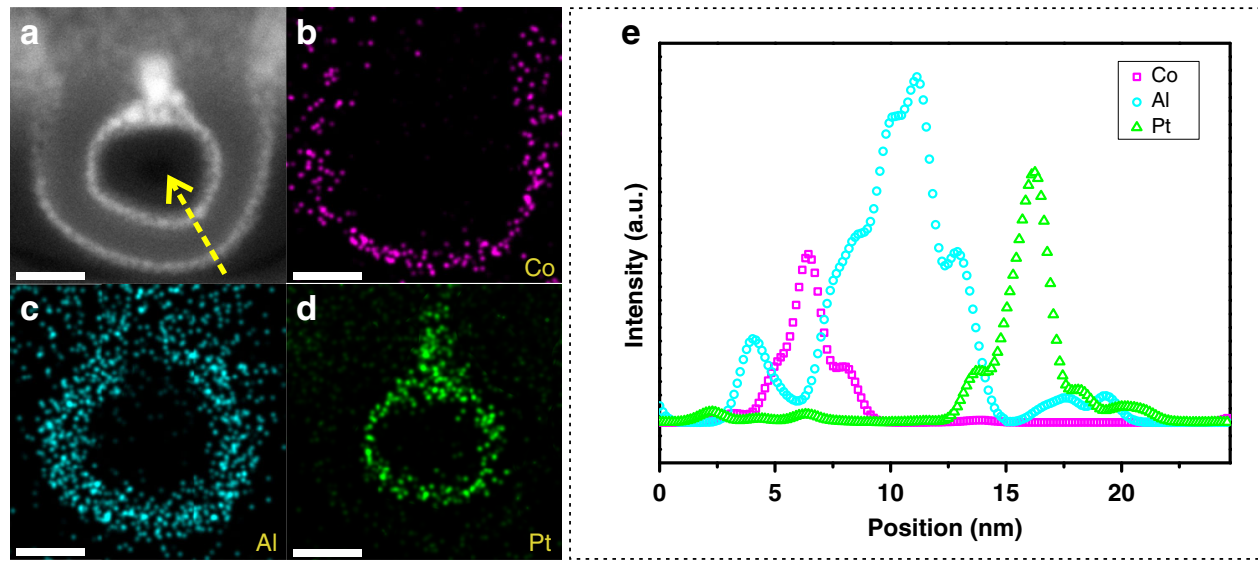

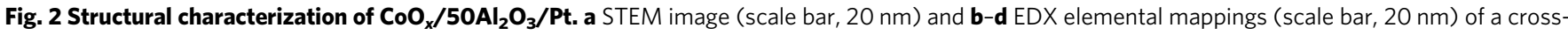
sectional specimen of $\mathrm{CoO}_{x} / 50 \mathrm{Al}_{2} \mathrm{O}_{3} / \mathrm{Pt}$ prepared by focused ion beam milling. e Compositional point profile of $\mathrm{Co}$, $\mathrm{Al}$, and $\mathrm{Pt}$ from the specimen recorded along the yellow arrow shown in $\mathbf{a}$

organic synthesis ${ }^{41,42}$. The catalytic performances of different catalysts for the styrene epoxidation reaction with tert-butyl hydroperoxide (TBHP) as the oxidant are summarized in Table 1. Styrene was negligibly converted without a catalyst (Table 1, entry 1). For $50 \mathrm{Al}_{2} \mathrm{O}_{3} / \mathrm{Pt}$, only a $17.7 \%$ conversion was obtained (Table 1, entry 2). When Co-based catalysts were added, SO was formed as the major product, and benzaldehyde $(\mathrm{BzH})$ was produced as a byproduct. For $\mathrm{CoO}_{x} / 50 \mathrm{Al}_{2} \mathrm{O}_{3}$, the reaction can be efficiently catalyzed, with $93 \%$ conversion and $74.3 \%$ SO selectivity (Table 1 , entry 3 ). All of the attempts, including the prereduction treatment (Table 1, entry 4), the increase of the ratio of TBHP/styrene (Supplementary Fig. 9), the addition of a $\mathrm{Pt}$ component to the catalyst (namely $\mathrm{CoO}_{x} / 50 \mathrm{Al}_{2} \mathrm{O}_{3} / \mathrm{Pt}$ ) (Table 1 , entry 6), and the introduction of $\mathrm{H}_{2}$ into the reaction system $\left(\mathrm{H}_{2}\right.$ TBHP) (Table 1, entry 5), failed to enhance the SO selectivity of $\mathrm{CoO}_{x} / 50 \mathrm{Al}_{2} \mathrm{O}_{3}$. However, when $\mathrm{H}_{2}$ was introduced into the reaction, the SO selectivity $(94.8 \%)$ of $\mathrm{CoO}_{x} / 50 \mathrm{Al}_{2} \mathrm{O}_{3} / \mathrm{Pt}$ in the $\mathrm{H}_{2}$-TBHP condition (Table 1, entry 7) was remarkably increased by $20.5 \%$ compared to $\mathrm{CoO}_{x} / 50 \mathrm{Al}_{2} \mathrm{O}_{3}$ in the TBHP condition. Although its conversion (82.5\%) was slightly reduced, the decreased conversion was easily compensated by prolonging the reaction time. During the entire reaction process, the SO selectivity of the $\mathrm{CoO}_{x} / 50 \mathrm{Al}_{2} \mathrm{O}_{3} / \mathrm{Pt}$ in the $\mathrm{H}_{2}$-TBHP condition is greatly higher compared with that of the $\mathrm{CoO}_{x} / 50 \mathrm{Al}_{2} \mathrm{O}_{3}$ in the TBHP condition under the same styrene conversion (Supplementary Fig. 10). After reaction, the distributions of the inner Pt 

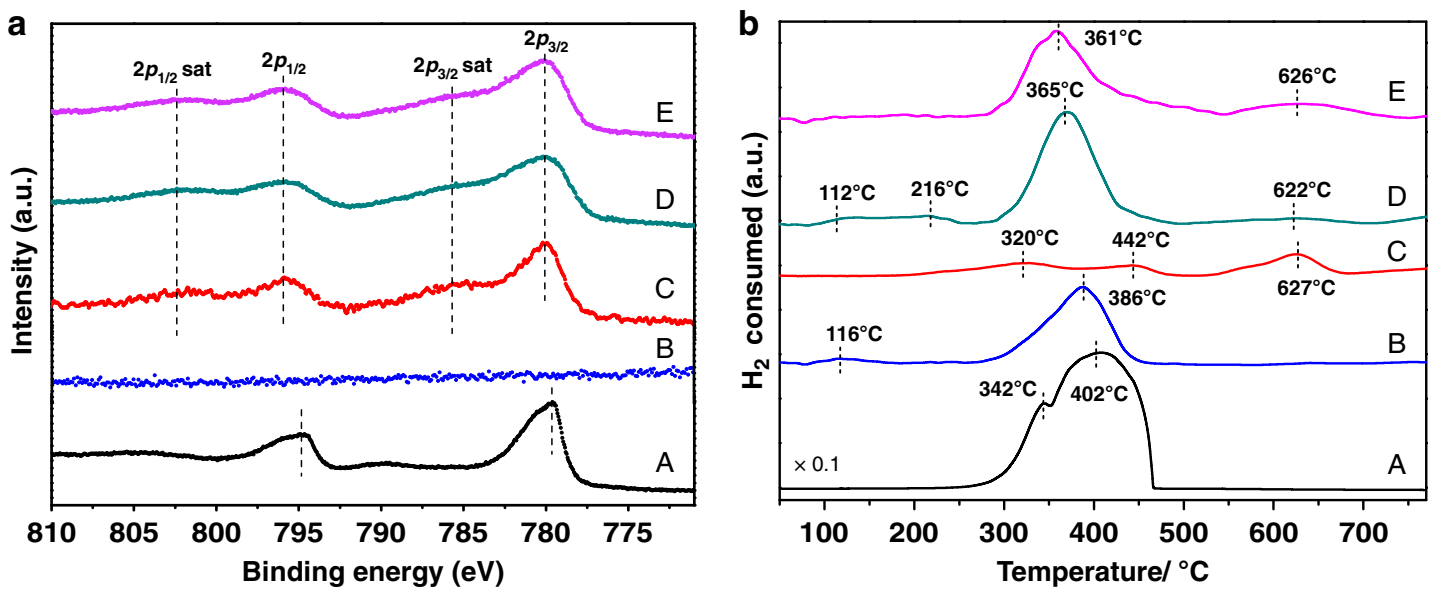

Fig. 3 Electronic structure and chemisorption characterizations. a XPS Co $2 p$ analysis and $\mathbf{b} \mathrm{H}_{2}-\mathrm{TPR}$ profiles of $(\mathrm{A}) \mathrm{Co}_{3} \mathrm{O}_{4}$ as reference, $(\mathrm{B}) 50 \mathrm{Al} \mathrm{O}_{3} / \mathrm{Pt}_{\text {, }}$ (C) $\mathrm{CoO}_{x} / 50 \mathrm{Al}_{2} \mathrm{O}_{3}$, (D) $\mathrm{CoO}_{x} / 50 \mathrm{Al}_{2} \mathrm{O}_{3} / \mathrm{Pt}$, and (E) $\mathrm{CoO}_{x} / 100 \mathrm{Al}_{2} \mathrm{O}_{3} / \mathrm{Pt}$.

Table 1 Catalytic performances of the catalysts for styrene epoxidation reaction in different conditions ${ }^{a}$.

\begin{tabular}{lllcc} 
Entry & Atmosphere & Catalysts & Conversion (\%) & so sel. (\%) \\
\hline 1 & - & - & 9.9 & 37.6 \\
2 & - & $50 \mathrm{Al}_{2} \mathrm{O}_{3} / \mathrm{Pt}$ & 17.7 & 72.4 \\
3 & - & $\mathrm{CoO}_{x} / 50 \mathrm{Al}_{2} \mathrm{O}_{3}$ & 93.0 & 74.3 \\
4 & - & $\mathrm{Pre}_{2}-\mathrm{reduced} \mathrm{CoO}_{x} / 50 \mathrm{Al}_{2} \mathrm{O}_{3} \mathrm{~b}$ & 73.7 \\
5 & $\mathrm{H}_{2}$ & $\mathrm{CoO}_{x} / 50 \mathrm{Al}_{2} \mathrm{O}_{3}$ & 91.2 & 75.9 \\
6 & - & $\mathrm{CoO}_{x} / 50 \mathrm{Al}_{2} \mathrm{O}_{3} / \mathrm{Pt}$ & 89.8 & 76.2 \\
7 & $\mathrm{CoO}_{2}$ & $\mathrm{CoO}_{x} / 50 \mathrm{Al}_{2} \mathrm{O}_{3} / \mathrm{Pt}$ & 93.4 & 94.8 \\
\hline
\end{tabular}

aReaction conditions: $3.5 \mathrm{mmol}$ styrene, $7 \mathrm{mmol}$ TBHP $\left(70 \%\right.$ in water), $20 \mathrm{ml}$ acetonitrile and catalysts with the same $\mathrm{CoO}_{x}$ content at $80{ }^{\circ} \mathrm{C}$ for $8 \mathrm{~h}$

bReducing $\mathrm{CoO}_{x} / 50 \mathrm{Al}_{2} \mathrm{O}_{3}$ at $350^{\circ} \mathrm{C}$ for $1 \mathrm{~h}$ before reaction.
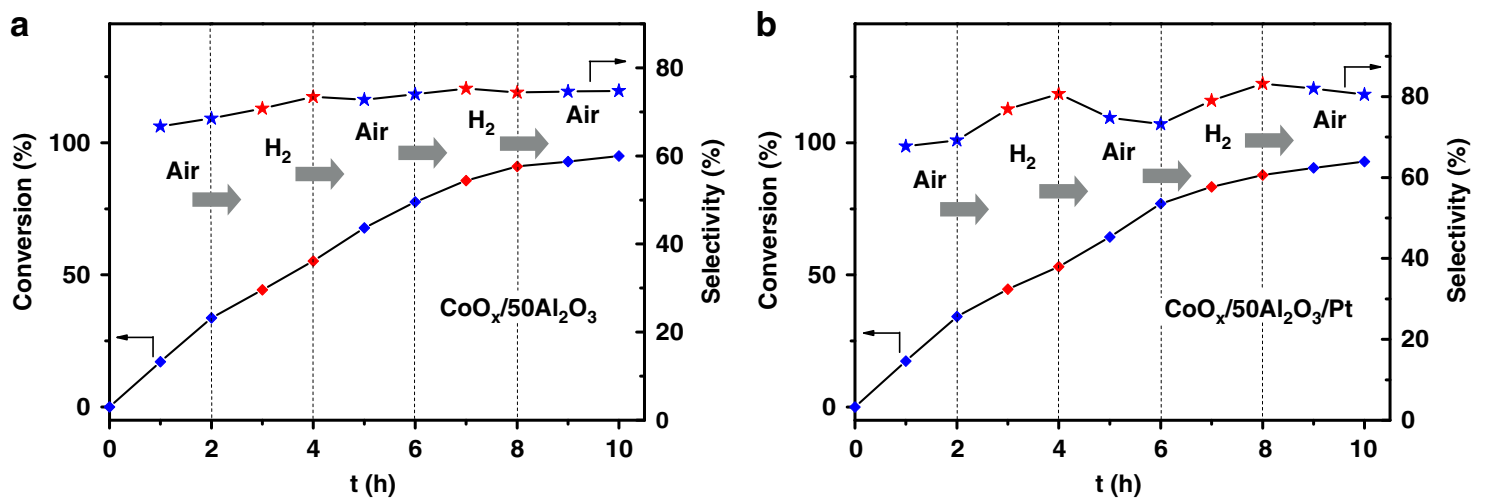

Fig. $4 \mathbf{H}_{\mathbf{2}}$ pulse experiments. The evolution of styrene conversion and $\mathrm{SO}$ selectivity with reaction atmosphere and time over a $\mathrm{CoO}_{x} / 50 \mathrm{Al}{ }_{2} \mathrm{O}_{3}$ and b $\mathrm{CoO}_{x} / 50 \mathrm{Al}_{2} \mathrm{O}_{3} / \mathrm{Pt}$.

and the outer $\mathrm{CoO}_{x}$ nanoparticles for $\mathrm{CoO}_{x} / 50 \mathrm{Al}_{2} \mathrm{O}_{3} / \mathrm{Pt}$ remain (Supplementary Fig. 11), and no obvious detachment of nanoparticles is observed, indicating that the catalyst is stable during the reaction.

Further, $\mathrm{H}_{2}$ pulse experiments were carried out for $\mathrm{CoO}_{x} /$ $50 \mathrm{Al}_{2} \mathrm{O}_{3}$ and $\mathrm{CoO}_{x} / 50 \mathrm{Al}_{2} \mathrm{O}_{3} / \mathrm{Pt}$ with alternating pulse of $\mathrm{H}_{2}$ and air (Fig. 4a, b). During the reaction, for $\mathrm{CoO}_{x} / 50 \mathrm{Al}_{2} \mathrm{O}_{3}$, the conversion and selectivity were almost unaffected by the alternate reaction atmosphere. For $\mathrm{CoO}_{x} / 50 \mathrm{Al}_{2} \mathrm{O}_{3} / \mathrm{Pt}$, when air was displaced by $\mathrm{H}_{2}$, the increase of conversion slowed down and the SO selectivity was increased obviously. When $\mathrm{H}_{2}$ was displaced by air, the opposite phenomenon occurred. This control experiment straightforwardly indicates that the introduction of active hydrogen $\left(\mathrm{Pt}\right.$ and $\mathrm{H}_{2}$ ) plays an essential role in enhancing the selectivity of the catalysts for styrene epoxidation reaction.

The effect of the distance between $\mathrm{CoO}_{x}$ and $\mathrm{Pt}$ components corresponding to the thicknesses of the $\mathrm{Al}_{2} \mathrm{O}_{3}$ layer on the catalytic performance has been investigated (Table 2 and Supplementary Table 5). The thicknesses of the $\mathrm{Al}_{2} \mathrm{O}_{3}$ layer are precisely regulated by varying the cycle numbers of $\mathrm{ALD} \mathrm{Al}_{2} \mathrm{O}_{3}$. In TBHP condition, the catalytic performances of $\mathrm{CoO}_{x} / y \mathrm{Al}_{2} \mathrm{O}_{3} / \mathrm{Pt}$ 
Table 2 Catalytic performances of the catalysts with different $\mathrm{Al}_{2} \mathrm{O}_{3}$ cycles for styrene epoxidation reaction.

\begin{tabular}{|c|c|c|c|c|c|c|}
\hline Entry & Catalysts & Distance (nm) & \multicolumn{2}{|l|}{ TBHP condition } & \multicolumn{2}{|c|}{$\mathrm{H}_{2}-\mathrm{TBHP}$ condition } \\
\hline 1 & $\mathrm{CoO}_{x} / 35 \mathrm{Al}_{2} \mathrm{O}_{3} / \mathrm{Pt}$ & 5 & 91.0 & 77.5 & 83.5 & 93.9 \\
\hline 3 & $\mathrm{CoO}_{x} / 65 \mathrm{Al}_{2} \mathrm{O}_{3} / \mathrm{Pt}$ & 9 & 92.5 & 78.2 & 85.6 & 86.5 \\
\hline 4 & $\mathrm{CoO}_{x} / 80 \mathrm{Al}_{2} \mathrm{O}_{3} / \mathrm{Pt}$ & 11 & 93.0 & 76.4 & 89.0 & 77.1 \\
\hline 5 & $\mathrm{CoO}_{x} / 100 \mathrm{Al}_{2} \mathrm{O}_{3} / \mathrm{Pt}$ & 14 & 92.0 & 76.3 & 90.2 & 76.8 \\
\hline
\end{tabular}
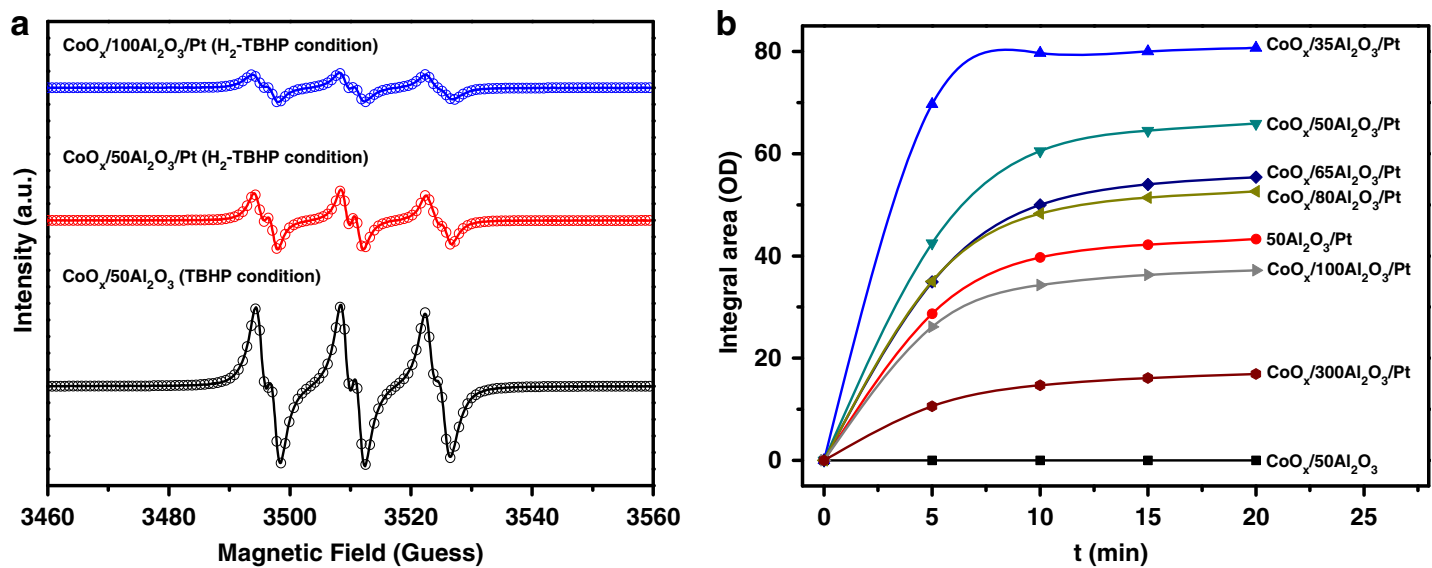

Fig. 5 Catalytic mechanism analyses. a Experimental EPR spectra (lines) and simulated spectra (open circles) for a mixture of $\mathrm{PBN}-\mathrm{OOC}\left(\mathrm{CH}_{3}\right)_{3}$ and PBN-OC $\left(\mathrm{CH}_{3}\right)_{3}$. b Intensity of the $v(\mathrm{OD})$ band during exposure of samples in $\left(\mathrm{D}_{2}: \mathrm{H}_{2}=1: 1\right)$ at a total $\mathrm{D}_{2} / \mathrm{H}_{2}$ flow rate of $30 \mathrm{ml} \mathrm{min}{ }^{-1}$ at $80{ }^{\circ} \mathrm{C}$ and 1 atm.

are similar. However, when $\mathrm{H}_{2}$ was introduced, their catalytic performances exhibited obvious differences. Varying the cycle numbers of $\mathrm{ALD} \mathrm{Al}_{2} \mathrm{O}_{3}$ from 35 to 65 , the activities of the three catalysts in the $\mathrm{H}_{2}$-TBHP condition decreased compared with those of the corresponding catalysts in the TBHP condition, whereas the $\mathrm{SO}$ selectivities show obvious improvements with the highest value of $94.8 \%$ for $\mathrm{CoO}_{x} / 50 \mathrm{Al}_{2} \mathrm{O}_{3} / \mathrm{Pt}$ (Table 2, entries $1-3$ ). With a further increase of cycle numbers (over 80 ), the activities and $\mathrm{SO}$ selectivities of $\mathrm{CoO}_{x} / 80 \mathrm{Al}_{2} \mathrm{O}_{3} / \mathrm{Pt}, \mathrm{CoO}_{x} /$ $100 \mathrm{Al}_{2} \mathrm{O}_{3} / \mathrm{Pt}$, and $\mathrm{CoO}_{x} / 300 \mathrm{Al}_{2} \mathrm{O}_{3} / \mathrm{Pt}$ in the $\mathrm{H}_{2}$-TBHP condition are similar to that of the corresponding catalysts in the TBHP condition (Table 2, entries 4-6). At low conversions, $\mathrm{CoO}_{x} /$ $50 \mathrm{Al}_{2} \mathrm{O}_{3} / \mathrm{Pt}$ catalyst also exhibits the greatest improvement of $\mathrm{SO}$ selectivity among these catalysts (Supplementary Fig. 12). Therefore, it can be seen that a precisely controlled $\mathrm{CoO}_{x}-\mathrm{Pt}$ distance is critically important for the remarkably enhanced SO selectivity.

Catalytic mechanism. To uncover the potential mechanism for the enhanced SO selectivity, a series of experiments and characterizations were carried out. Isotope-labeling experiments were conducted to track the transfer pathways of split hydrogen species. For $\mathrm{CoO}_{x} / 50 \mathrm{Al}_{2} \mathrm{O}_{3} / \mathrm{Pt}$ in the $\mathrm{D}_{2}$-TBHP condition, the deuterium signal was not found in the mass spectrometry results of $\mathrm{BzH}$ and SO (Supplementary Fig. 13), demonstrating that the active hydrogen species were not directly involved in the oxidation of organic substrates.

A free radical scavenger (butylated hydroxytoluene, BHT) was added to the reaction to further study the reaction mechanism. For $\mathrm{CoO}_{x} / 50 \mathrm{Al}_{2} \mathrm{O}_{3}$ in the TBHP condition, and $\mathrm{CoO}_{x} / 50 \mathrm{Al}_{2} \mathrm{O}_{3} / \mathrm{Pt}$ and $\mathrm{CoO}_{x} / 100 \mathrm{Al}_{2} \mathrm{O}_{3} / \mathrm{Pt}$ in the $\mathrm{H}_{2}$-TBHP condition, the conversion of styrene stopped after the addition of BHT (Supplementary
Fig. 14), indicating that the radical pathway has an important contribution to the reaction mechanism. Moreover, according to the electron paramagnetic resonance (EPR) results (Fig. 5a, Supplementary Fig. 15, and Supplementary Table 6), two kinds of radicals, i.e., tert-butylperoxy and tert-butyloxy radicals (tBuOO. and $\mathrm{tBuO} \cdot)$, can be detected in the three cases. These results indicate that the styrene epoxidation reaction over Co-based catalysts experienced a radical process, and the kinds of the radicals were the same in the three cases.

The existence of hydrogen spillover from $\mathrm{Pt}$ to $\mathrm{CoO}_{x}$ through the nonreducible $\mathrm{Al}_{2} \mathrm{O}_{3}$ support was confirmed by $\mathrm{H}-\mathrm{D}$ exchange experiments (Fig. 5b and Supplementary Fig. 16). Figure 5b shows the $\mathrm{H}-\mathrm{D}$ exchange rates of $\mathrm{CoO}_{x} / 50 \mathrm{Al}_{2} \mathrm{O}_{3}, 50 \mathrm{Al}_{2} \mathrm{O}_{3} / \mathrm{Pt}$, and $\mathrm{CoO}_{x} /$ $y \mathrm{Al}_{2} \mathrm{O}_{3} / \mathrm{Pt}(y=35,50,65,80,100$, and 300), indicating that the flux of spilled deuterium species from $\mathrm{Pt}$ to $\mathrm{CoO}_{x}$ on the nonreducible $\mathrm{Al}_{2} \mathrm{O}_{3}$ support decreases with increasing distance. The hydrogen spillover was also confirmed by the color change in the mixture of the catalyst and $\mathrm{WO}_{3}$ nanowires (Supplementary Fig. 17). There are debates on the existence of hydrogen spillover on nonreducible support $\left(\mathrm{SiO}_{2}, \mathrm{Al}_{2} \mathrm{O}_{3}\right.$, and zeolite). It was argued that hydrogen spillover to defect-free surfaces of nonreducible metal oxides cannot take place, but spillover to a non-reducible support with defects is possible ${ }^{16}$. In recent years, more and more evidence demonstrates that although $\mathrm{Al}_{2} \mathrm{O}_{3}$ is a non-reducible oxide, hydrogen spillover can occur on $\mathrm{it}^{25,43-49}$. In this work, the obtained $\mathrm{Al}_{2} \mathrm{O}_{3}$ is amorphous (Supplementary Fig. 7) and thus many defects exist. The nonreducible $\mathrm{Al}_{2} \mathrm{O}_{3}$ support was calcined at high temperature, which may result in the formation of a small amount of micropores ${ }^{50}$. Thus, the active hydrogen species may spill over the surface of the micropores or through the defects of $\mathrm{Al}_{2} \mathrm{O}_{3}$ layer.

To reveal the electronic structures of cobalt species, X-ray absorption fine structure (XAFS) of the catalysts was investigated 

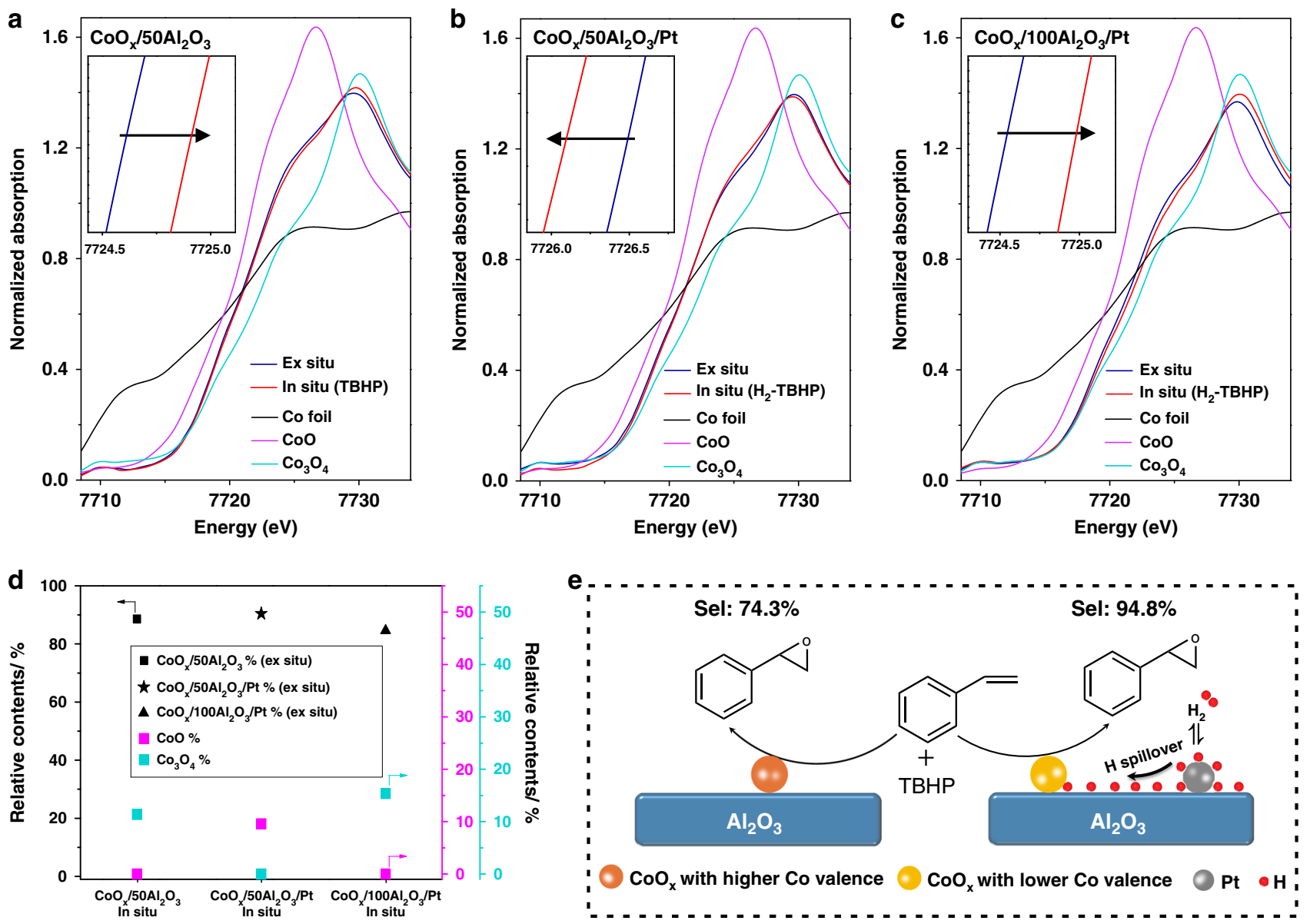

Fig. 6 XANES spectra of the catalysts and proposed mechanisms. a-c Ex situ and in situ Co K-edge XANES spectra of $\mathrm{CoO}_{x} / 50 \mathrm{Al}_{2} \mathrm{O}_{3}, \mathrm{CoO}_{x} / 50 \mathrm{Al}{ }_{2} \mathrm{O}_{3} / \mathrm{Pt}_{\text {, }}$ and $\mathrm{CoO}_{x} / 100 \mathrm{Al}_{2} \mathrm{O}_{3} / \mathrm{Pt}$, and spectra of reference samples ( $\mathrm{Co}$ foil, $\mathrm{CoO}$, and $\mathrm{CO}_{3} \mathrm{O}_{4}$ ). Insets show the expanded sections of absorption edges. $\mathbf{d}$ The results of the linear combination fitting for the in situ spectra of the catalysts. For each catalyst, the in-situ spectrum is fitted by a linear combination of the ex-situ spectrum and the spectra of reference samples $\left(\mathrm{CO}_{3} \mathrm{O}_{4}\right.$ and $\left.\mathrm{CoO}\right)$. e Proposed reaction mechanisms for $\mathrm{CoO}_{x} / 50 \mathrm{Al}_{2} \mathrm{O}_{3}$ in the TBHP condition and $\mathrm{CoO}_{x} / 50 \mathrm{Al}_{2} \mathrm{O}_{3} / \mathrm{Pt}$ in the $\mathrm{H}_{2}$-TBHP condition. In the presence of controllable hydrogen spillover, cobalt species with a lower valence state are beneficial to the enhanced selectivity.

(Fig. 6a-c). The ex situ X-ray absorption near-edge structure (XANES) profiles show that the positions of the white line peaks for the $\mathrm{CoO}_{x} / 50 \mathrm{Al}_{2} \mathrm{O}_{3}, \mathrm{CoO}_{x} / 50 \mathrm{Al}_{2} \mathrm{O}_{3} / \mathrm{Pt}$, and $\mathrm{CoO}_{x} / 100 \mathrm{Al}_{2} \mathrm{O}_{3} / \mathrm{Pt}$ are all located between the peaks of the rock-salt $\mathrm{CoO}$ and spinel $\mathrm{Co}_{3} \mathrm{O}_{4}$, indicating that the oxidation states of cobalt species for as-prepared catalysts include both $\mathrm{Co}^{3+}$ and $\mathrm{Co}^{2+}$, which is consistent with the XPS result. In the presence of TBHP, compared with the ex situ spectrum, the absorption edge of the in-situ spectrum for $\mathrm{CoO}_{x} / 50 \mathrm{Al}_{2} \mathrm{O}_{3}$ shifted to higher energy (Fig. 6a), revealing that the cobalt species in the reaction is at a higher oxidation state. The changes in the valence of catalyst are not significant, because of the mild reaction conditions $\left(80^{\circ} \mathrm{C}\right.$ and atmosphere pressure). When $\mathrm{H}_{2}$ was introduced into the reaction system, no obvious difference was observed in the $\mathrm{H}_{2}$-TBHP condition compared with in the TBHP condition for $\mathrm{CoO}_{x} /$ $50 \mathrm{Al}_{2} \mathrm{O}_{3}$ (Supplementary Fig. 18). For $\mathrm{CoO}_{x} / 100 \mathrm{Al}_{2} \mathrm{O}_{3} / \mathrm{Pt}$, a distinct increase in the cobalt oxidation state was also observed in the reaction $\left(\mathrm{H}_{2}-\mathrm{TBHP}\right.$ condition) (Fig. 6c). However, for $\mathrm{CoO}_{x} /$ $50 \mathrm{Al}_{2} \mathrm{O}_{3} / \mathrm{Pt}$, the absorption edge of the in-situ spectrum shifted to lower energy (Fig. 6b), meaning a decrease in the cobalt oxidation state in the $\mathrm{H}_{2}$-TBHP condition. To quantitatively reveal the change in the cobalt oxidation states during the reaction, the insitu XANES spectrum is simulated by a linear combination of the ex-situ spectrum of the as-prepared catalyst and the spectra of reference samples $\left(\mathrm{Co}_{3} \mathrm{O}_{4}\right.$ and $\left.\mathrm{CoO}\right)$ (Supplementary Fig. 19 and
Supplementary Table 7). For $\mathrm{CoO}_{x} / 50 \mathrm{Al}_{2} \mathrm{O}_{3}$ in the TBHP condition and $\mathrm{CoO}_{x} / 100 \mathrm{Al}_{2} \mathrm{O}_{3} / \mathrm{Pt}$ in the $\mathrm{H}_{2}$-TBHP condition, extra $\mathrm{Co}_{3} \mathrm{O}_{4}$ (11.4\% and $15.4 \%$, respectively) is formed, as shown in Fig. 6d. However, for $\mathrm{CoO}_{x} / 50 \mathrm{Al}_{2} \mathrm{O}_{3} / \mathrm{Pt}$ in the $\mathrm{H}_{2}$-TBHP condition, extra $\mathrm{CoO}(9.6 \%)$ is formed. The $k^{2}$-weighted Fouriertransformed extended X-ray absorption fine structure (FTEXAFS) spectra (Supplementary Fig. 20) and their curve fitting results (Supplementary Table 8 ) are consistent with the conclusions drawn from the XANES experiments.

\section{Discussion}

Our results show that epoxidation selectivity can be obviously enhanced after controllable hydrogen spillover was introduced. The possible reasons of the enhanced selectivity were revealed by detailed experiments and characterizations.

After $\mathrm{Pt}$ and $\mathrm{H}_{2}$ were introduced into the epoxidation reaction, the $\mathrm{CoO}_{x}$ catalyzed epoxidation reaction still experienced a radical process and the kinds of radicals were the same, which can be concluded from the radical scavenging and EPR results. On the other hand, for $\mathrm{CoO}_{x} / y \mathrm{Al}_{2} \mathrm{O}_{3} / \mathrm{Pt}$, they are similar in sizes of nanoparticles (TEM and XRD) and pore diameter $\left(\mathrm{N}_{2}\right.$ sorption) regardless of the thicknesses of $\mathrm{Al}_{2} \mathrm{O}_{3}$. Their catalytic performances are similar in TBHP condition. Moreover, the prereduction treatment of $\mathrm{CoO}_{x} / 50 \mathrm{Al}_{2} \mathrm{O}_{3}$ further indicates the 
enhanced selectivity is not ascribed to the ex-situ oxidation states of fresh catalysts.

In contrast, when $\mathrm{H}_{2}$ was introduced into the reaction, the catalytic performances of the $\mathrm{CoO}_{x} / y \mathrm{Al}_{2} \mathrm{O}_{3} / \mathrm{Pt}$ with different $\mathrm{Al}_{2} \mathrm{O}_{3}$ thicknesses exhibited obvious differences. The color change of $\mathrm{WO}_{3}$ nanowires and $\mathrm{H}-\mathrm{D}$ exchange experiments suggest that when $\mathrm{H}_{2}$ was introduced into the reaction system, hydrogen spillover can occur and the strength of hydrogen spillover decreases with increasing distance, which is in good accordance with the TPR result. Moreover, isotope-labeling experiments demonstrate that the active hydrogen species are not directly involved in the oxidation of organic substrates. For the catalyst with enhanced selectivity, the $\mathrm{CoO}_{x}-\mathrm{Pt}$ distance (several nanometers) is comparable to the distance of hydrogen spillover on $\mathrm{Al}_{2} \mathrm{O}_{3}$, implying that the controllable hydrogen spillover is responsible for the enhanced selectivity. The in situ XAFS results further confirm the explanation. It clearly reveals that the electronic structures of cobalt species during the epoxidation reaction can be successfully modulated through controlling the hydrogen spillover distance. For $\mathrm{CoO}_{x} / 50 \mathrm{Al}_{2} \mathrm{O}_{3} / \mathrm{Pt}$ in $\mathrm{H}_{2}$-TBHP condition, the cobalt species are reduced to a lower oxidation state, while for $\mathrm{CoO}_{x} / 50 \mathrm{Al}_{2} \mathrm{O}_{3}$ in TBHP condition and $\mathrm{CoO}_{x} / 100 \mathrm{Al}_{2} \mathrm{O}_{3} / \mathrm{Pt}$ in $\mathrm{H}_{2}$-TBHP condition, the cobalt species are oxidized to a higher oxidation state. For the epoxidation reaction, one common understanding of the reaction mechanism is recognized that catalysts affect the reactions by bonding of oxygen to the metal ${ }^{51-54}$. The electronic structure of catalyst at reaction conditions affects the strength of the $\mathrm{Co}-\mathrm{O}$ bond in the catalyst, which further determines the selectivity of epoxides.

In addition to hydrogen spillover on the $\mathrm{Al}_{2} \mathrm{O}_{3}$ support, other possible migration mechanisms of active hydrogen species, including carbon impurities and water-assisted $\mathrm{H}$ shuttling, are also considered. Carbon impurities are proposed as an alternative hydrogen migration path on nonreducible support ${ }^{16}$. Waterassisted $\mathrm{H}$ shuttling can accelerate proton transfer and is proposed to explain the enhanced performance observed in the presence of water for hydrogenation reactions ${ }^{55,56}$. However, the distance of hydrogen spillover on carbon species is far beyond the range of several nanometers ${ }^{11,24}$. Similarly, hydrogen shuttling is a remote promotional effect ${ }^{57}$. These mechanisms cannot fit our catalytic results well.

Based on all above results, it can be concluded that the enhanced selectivity is attributed to the introduction of controllable hydrogen spillover, which is further confirmed by the $\mathrm{H}_{2}$ pulse experiments. In the presence of controllable hydrogen spillover, cobalt species with a lower valence state are more beneficial for enhanced catalytic selectivity, as shown in Fig. 6e. Based on the successful demonstration of in-situ tailoring of Co valence by hydrogen spillover, we can expect that the selectivity can also be changed over a $\mathrm{CoO}_{x} \mathrm{Pt} / 50 \mathrm{Al}_{2} \mathrm{O}_{3}$ catalyst with the closely contacted $\mathrm{Pt}$ and $\mathrm{CoO}_{x}$ (Supplementary Fig. 21) due to the effect of hydrogen spillover. As expected, the SO selectivity of $\mathrm{CoO}_{x} \mathrm{Pt} / 50 \mathrm{Al}_{2} \mathrm{O}_{3}$ in the $\mathrm{H}_{2}$-TBHP condition is also increased compared to that in the TBHP condition (Supplementary Table 9). This further confirms that the introduction of controllable hydrogen spillover is responsible for the enhanced selectivity.

The strategy by introducing controllable hydrogen spillover into reaction was also successfully applied to the epoxidation of a variety of styrene derivatives (Table 3). In all cases, $\mathrm{CoO}_{x} /$ $50 \mathrm{Al}_{2} \mathrm{O}_{3} / \mathrm{Pt}$ exhibits greatly enhanced selectivities (up to over 90\%) via the introduction of controllable hydrogen spillover. Further, the $\mathrm{Pt} / 50 \mathrm{Al}_{2} \mathrm{O}_{3} / \mathrm{CoO}_{x}$ (Supplementary Fig. 22), which was produced by exchanging the deposition sequences of $\mathrm{Pt}$ and $\mathrm{CoO}_{x}$ nanoparticles, also exhibits enhanced SO selectivity through the introduction of controllable hydrogen spillover (Supplementary Table 10). In addition to cobalt catalysts, iron catalysts were also applied for styrene epoxidation. The SO selectivity of $\mathrm{FeO}_{x} / 50 \mathrm{Al}_{2} \mathrm{O}_{3} / \mathrm{Pt}$ in the $\mathrm{H}_{2}$-TBHP condition is higher than that of $\mathrm{FeO}_{x} / 50 \mathrm{Al}_{2} \mathrm{O}_{3}$ in the TBHP condition (Supplementary Fig. 23). These results demonstrate that the introduction of controllable hydrogen spillover for enhanced selectivity is a general method.

In summary, we have demonstrated a strategy, involving the introduction of controllable hydrogen spillover to the styrene epoxidation reaction to in situ tune the electronic structure of cobalt species for enhanced SO selectivity. The strength of hydrogen spillover from Pt nanoparticles to $\mathrm{CoO}_{x}$ was tuned by altering the thickness (ALD cycles) of the separating $\mathrm{Al}_{2} \mathrm{O}_{3}$ layer. When the thickness of the $\mathrm{Al}_{2} \mathrm{O}_{3}$ layer was $7 \mathrm{~nm}$, the catalyst $\left(\mathrm{CoO}_{x} / 50 \mathrm{Al}_{2} \mathrm{O}_{3} / \mathrm{Pt}\right)$ in the $\mathrm{H}_{2}$-TBHP condition exhibited significantly enhanced SO selectivity (over 20\%) compared with the $\mathrm{CoO}_{x} / 50 \mathrm{Al}_{2} \mathrm{O}_{3}$ catalyst in the TBHP condition. Our method of in situ electronic structure regulation, achieved through controllable hydrogen spillover, can be used for other catalytic reactions.

\section{Methods}

Synthesis of $\mathbf{5 O A l}_{\mathbf{2}} \mathbf{O}_{\mathbf{3}} / \mathrm{Pt}$ catalysts. The synthesis of CNCs and the ALD process can be found in the Supplementary Methods. CNCs were firstly deposited with Pt nanoparticles ( 20 cycles) and then coated with an $\mathrm{Al}_{2} \mathrm{O}_{3}$ layer (50 cycles) by $\mathrm{ALD}$, producing $50 \mathrm{Al}_{2} \mathrm{O}_{3} / \mathrm{Pt} / \mathrm{CNCs}$. The $50 \mathrm{Al}_{2} \mathrm{O}_{3} / \mathrm{Pt} / \mathrm{CNCs}$ were calcinated at $500{ }^{\circ} \mathrm{C}$ for $1 \mathrm{~h}$ in air to remove the $\mathrm{CNC}$ templates, obtaining $50 \mathrm{Al}_{2} \mathrm{O}_{3} / \mathrm{Pt}$ catalysts.

Synthesis of $\mathrm{CoO}_{\mathbf{x}} / \mathbf{5 O A l}_{\mathbf{2}} \mathrm{O}_{\mathbf{3}}$ catalysts. CNCs were firstly coated with an $\mathrm{Al}_{2} \mathrm{O}_{3}$ layer ( 50 cycles) by ALD producing $\mathrm{Al}_{2} \mathrm{O}_{3} / \mathrm{CNCs}$, which were calcinated at $500{ }^{\circ} \mathrm{C}$ for $1 \mathrm{~h}$ in air. Then the obtained hollow $\mathrm{Al}_{2} \mathrm{O}_{3}$ nanotubes were deposited with $\mathrm{CoO}_{x}$ nanoparticles ( 35 cycles) by ALD, obtaining $\mathrm{CoO}_{x} / 50 \mathrm{Al}_{2} \mathrm{O}_{3}$ catalysts.

Table 3 Catalytic epoxidation of styrene derivatives in different conditions ${ }^{a}$.

\begin{tabular}{|c|c|c|c|c|c|}
\hline Catalysts & Condition & Substrates & $t(h)$ & Conversion (\%) & Epoxide sel. (\%) \\
\hline \multirow{5}{*}{$\mathrm{CoO}_{x} / 50 \mathrm{Al}_{2} \mathrm{O}_{3}$} & TBHP & p-methylstyrene & 12 & 97.1 & 88.4 \\
\hline & & p-methoxy-styrene & 12 & 80.5 & 78.2 \\
\hline & & $m$-nitrostyrene & 16 & 68.4 & 68.2 \\
\hline & & $m$-chlorostyrene & 12 & 88.7 & 69.9 \\
\hline & & 2-vinyl naphthalene & 12 & 82.1 & 79.8 \\
\hline \multirow[t]{5}{*}{$\mathrm{CoO}_{x} / 50 \mathrm{Al}_{2} \mathrm{O}_{3} / \mathrm{Pt}$} & $\mathrm{H}_{2}-\mathrm{TBHP}$ & $p$-methylstyrene & 12 & 86.2 & 98.2 \\
\hline & & $p$-methoxy-styrene & 12 & 68.1 & 94.3 \\
\hline & & $m$-nitrostyrene & 16 & 59.2 & 92.3 \\
\hline & & $m$-chlorostyrene & 12 & 81.1 & 89.4 \\
\hline & & 2-vinyl naphthalene & 12 & 71.5 & 91.5 \\
\hline
\end{tabular}

aReaction conditions: $3.5 \mathrm{mmol}$ substrates, $7 \mathrm{mmol}$ TBHP $\left(70 \%\right.$ in water), $20 \mathrm{ml}$ acetonitrile, and catalysts with the same $\mathrm{CoO}_{x}$ content at $80^{\circ} \mathrm{C}$. 
Synthesis of $\mathrm{CoO}_{x} / \mathbf{y A l}_{\mathbf{2}} \mathrm{O}_{3} / \mathrm{Pt}$ catalysts. CNCs were firstly deposited with $\mathrm{Pt}$ nanoparticles and then coated with an $\mathrm{Al}_{2} \mathrm{O}_{3}$ layer $(y=35,50,65,80,100,300)$ by ALD. After $\mathrm{Al}_{2} \mathrm{O}_{3}$ deposition, CNCs were completely enclosed by compact ALD $\mathrm{Al}_{2} \mathrm{O}_{3}$. The obtained samples were calcinated at $500^{\circ} \mathrm{C}$ for $1 \mathrm{~h}$ in air and subsequently coated with $\mathrm{CoO}_{x}$ nanoparticles $(35$ cycles) by ALD, obtaining $\mathrm{CoO}_{x} / y \mathrm{Al}_{2} \mathrm{O}_{3} / \mathrm{Pt}$.

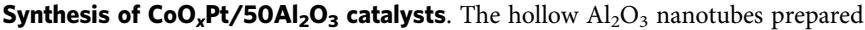
by the above method were deposited with $\mathrm{Pt}\left(20\right.$ cycles) and $\mathrm{CoO}_{x}$ nanoparticles ( 35 cycles) by ALD, obtaining $\mathrm{CoO}_{x} \mathrm{Pt} / 50 \mathrm{Al}_{2} \mathrm{O}_{3}$ catalysts.

Synthesis of $\mathbf{P t} / \mathbf{5 0 A l} \mathbf{O}_{3} / \mathbf{C o O}_{x}$ catalysts. CNCs were firstly deposited with $\mathrm{CoO}_{x}$ nanoparticles ( 35 cycles) and then coated with an $\mathrm{Al}_{2} \mathrm{O}_{3}$ layer ( 50 cycles) by ALD. The obtained samples were calcinated at $500^{\circ} \mathrm{C}$ for $1 \mathrm{~h}$ in air and subsequently coated with Pt nanoparticles ( 20 cycles) by ALD, obtaining $\mathrm{Pt} / 50 \mathrm{Al}_{2} \mathrm{O}_{3} /$ $\mathrm{CoO}_{x}$.

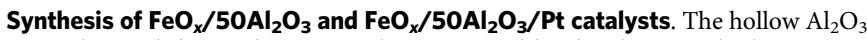
nanotubes and the $50 \mathrm{Al}_{2} \mathrm{O}_{3} / \mathrm{Pt}$ catalysts prepared by the above method were deposited with $\mathrm{FeO}_{x}$ nanoparticles (70 cycles) by ALD, obtaining $\mathrm{FeO}_{x} / 50 \mathrm{Al}_{2} \mathrm{O}_{3}$ and $\mathrm{FeO}_{x} / 50 \mathrm{Al}_{2} \mathrm{O}_{3} / \mathrm{Pt}$ catalysts, respectively.

Catalyst characterizations. FIB based on high-brightness Ga liquid-metal ion sources was recorded in FIB-SEM instrument (LYRA3 XMH, TESCAN). Typically, CNCs were first dispersed on a $\mathrm{Si}$ substrate and then were deposited by Pt and $\mathrm{Al}_{2} \mathrm{O}_{3}$ ALD. After calcination, the $\mathrm{CoO}_{x}$ was deposited. Then the $\mathrm{Si}$ substrate with the $\mathrm{CoO}_{\mathrm{x}} / 50 \mathrm{Al}_{2} \mathrm{O}_{3} / \mathrm{Pt}$ sample was transferred into the FIB-SEM system. The sample was first protected by a carbon layer. After that, a selected part of the protected $\mathrm{CoO}_{x} / 50 \mathrm{Al}_{2} \mathrm{O}_{3} / \mathrm{Pt}$ was lifted out of the Si substrate by FIB milling using $\mathrm{Ga}$ ion beam and then mounted on a TEM grid. Finally, the sample was sliced down to $\sim 100 \mathrm{~nm}$ along the vertical direction of the $\mathrm{Al}_{2} \mathrm{O}_{3}$ nanotubes by the $\mathrm{Ga}$ ion beam for TEM analysis. The EPR spectrums of the reaction solutions were recorded on a Bruker EMX spectrometer (EMXplus-10/12) using the following settings: frequency $9.862 \mathrm{GHz}$, sweep width $3460.0 \mathrm{G}$, time constant $60 \mathrm{~ms}$, modulation frequency $100 \mathrm{kHz}$, modulation width $0.5 \mathrm{G}$, microwave power $5 \mathrm{~mW}$. The spin trap N-tert-butyl- $\alpha$-phenylnitrone (PBN) was added into the reaction solutions to form radical adducts (1:1 molar ratio between the spin trap and TBHP). The solutions were filtered and the spectra were obtained at room temperature $(298 \mathrm{~K})$, using capillary tubes with the same dimensions as those used for the recording of the spectra of the catalysts. H-D exchange was characterized by in-situ infrared (IR) spectroscopy. IR spectra were recorded with a Bruker IFS 66v/S spectrometer with a resolution of $2 \mathrm{~cm}^{-1}$, and each spectrum is an average of 64 scans. The sample for IR spectroscopy was loaded into a diffuse reflectance infrared Fourier transform spectroscopy (DRIFTS) cell (Harrick Scientific Products, Praying MantisTM). The cell was connected to a flow system that allows recording of spectra while gases pass through and around the sample. The samples in IR cell were pretreated at $473 \mathrm{~K}$ for $1 \mathrm{~h}$ and then cooled down to $353 \mathrm{~K}$ in flowing $\mathrm{He}\left(30 \mathrm{~mL} \mathrm{~min}^{-1}\right)$. After the treatment, the samples were exposed to flowing gas $\left(\mathrm{H}_{2}\right.$ at $\left.30 \mathrm{~mL} \mathrm{~min}^{-1}\right)$ at $353 \mathrm{~K}$ for $1 \mathrm{~h}$, and then switched to flowing gas mixtures $\left(\mathrm{H}_{2}\right.$ at $15 \mathrm{~mL} \mathrm{~min}^{-1}, \mathrm{D}_{2}$ at $\left.15 \mathrm{~mL} \mathrm{~min}^{-1}\right)$ at $353 \mathrm{~K}$. The spectra of $\mathrm{H}-\mathrm{D}$ exchange were recorded. The ex situ and in situ XAFS were obtained on the 1W1B beamline of the Beijing Synchrotron Radiation Facility (BSRF), Institute of High Energy Physics, Chinese Academy of Sciences, and the BL14W1 beamline of the Shanghai Synchrotron Radiation Facility (SSRF), Shanghai Institute of Applied Physics, Chinese Academy of Sciences. A Si (111) double-crystal monochromator was used to reduce the harmonic component of the monochrome beam. Co foil, $\mathrm{CoO}$, and $\mathrm{Co}_{3} \mathrm{O}_{4}$ were used as reference samples and measured in transmission mode. IFEFFIT software was used to calibrate the energy scale, to correct the background signal and to normalize the intensity. The theoretical paths for $\mathrm{Co}-\mathrm{O}$ and Co-Co species used for fitting three coordination shells of the experimental data were generated using the FEFF7 program. The coordination number, bond distance, Debye-Waller factor, and inner potential correction were used as variable parameters for the fitting procedures. The in-situ XANES spectrum was simulated by a linear combination of the ex-situ spectrum of the as-prepared catalyst and the spectra of reference samples $\left(\mathrm{Co}_{3} \mathrm{O}_{4}\right.$ and $\left.\mathrm{CoO}\right)$. The following formula was used: (in situ XANES $)=f_{1} \cdot($ ex situ XANES $)+f_{2} \cdot\left(\right.$ XANES of $\left.\mathrm{Co}_{3} \mathrm{O}_{4}\right)+f_{3} \cdot($ XANES of $\mathrm{CoO}$ ), where $f_{1}, f_{2}$, and $f_{3}$ are the fractions of the as-prepared catalyst, $\mathrm{Co}_{3} \mathrm{O}_{4}$ and $\mathrm{CoO}$, respectively.

The other characterizations are provided in the Supplementary Methods.

Catalytic activity measurements. Styrene epoxidation reactions over the catalysts were carried out in a $50 \mathrm{ml}$ three-necked round bottom flask equipped with a magnetic stirrer in an oil bath. A mixture of catalysts with the same $\mathrm{CoO}_{x}$ content, $20 \mathrm{ml}$ acetonitrile, $3.5 \mathrm{mmol}$ styrene, and $7 \mathrm{mmol}$ TBHP (70\% TBHP in water) was introduced into the reaction vessel. Then, the reaction mixture was magnetically stirred and heated to $80^{\circ} \mathrm{C}$ at atmospheric pressure. When $\mathrm{H}_{2}$ was introduced into the reaction, the vessel was purged with purified hydrogen to remove the air at atmospheric pressure, and then was completely sealed with rubber plugs. Heating the reaction system to $80^{\circ} \mathrm{C}$, styrene was injected through needle tube. After reaction for $8 \mathrm{~h}$, the reaction mixture was separated and the liquid products collected were analyzed by gas chromatography-mass spectrometry (GC-MS, Agilent Technologies 7890A-5795C) with a capillary column (HP-5, $30 \mathrm{~m} \times 25 \mathrm{~mm} \times$ $0.25 \mu \mathrm{m}$ ). Free radical capture experiments were carried out by adding $2 \mathrm{mmol}$ quenchers (BHT) into the reaction system after $1 \mathrm{~h}$ reaction. $\mathrm{H}_{2}$ pulse experiments were carried out in a $50 \mathrm{ml}$ three-necked round bottom flask with alternating pulse of $\mathrm{H}_{2}$ and air. When the reaction atmosphere was displaced, the heating was stopped and each displaced process was maintained for $10 \mathrm{~min}$ with the gas flow rate of $30 \mathrm{sccm}$. Note that before each pulse, air or $\mathrm{H}_{2}$ was purged by inert gas nitrogen to ensure the safety. After displacement, the vessel was completely sealed and continued to be heated. The samples were collected every hour, and the reaction atmosphere was displaced every $2 \mathrm{~h}$.

\section{Safety notices}

Mixing hydrogen with an oxidant, in principle, may be not safe. In this paper, the risks are very minor considering mild reaction condition (low reaction temperature, atmospheric pressure, a small amount of $\mathrm{H}_{2}(30 \mathrm{ml})$, and a round bottom flask sealed with rubber plugs). If readers attempt to repeat it, please refer to the detailed experiment process in the section of "Catalytic activity measurements".

\section{Data availability}

The data that support the findings of this study are available from the corresponding author under reasonable request.

Received: 4 February 2020; Accepted: 25 August 2020; Published online: 22 September 2020

\section{References}

1. Noyori, R. Synthesizing our future. Nat. Chem. 1, 5-6 (2009).

2. Somorjai, G. A. \& Rioux, R. M. High technology catalysts towards $100 \%$ selectivity: fabrication, characterization and reaction studies. Catal. Today 100 , 201-215 (2005)

3. Peng, X. et al. Impact of hydrogenolysis on the selectivity of the Fischer-Tropsch synthesis: diesel fuel production over mesoporous zeolite-Ysupported cobalt nanoparticles. Angew. Chem. Int. Ed. Engl. 54, 4553-4556 (2015).

4. Corma, A., Serna, P., Concepcion, P. \& Calvino, J. J. Transforming nonselective into chemoselective metal catalysts for the hydrogenation of substituted nitroaromatics. J. Am. Chem. Soc. 130, 8748-8753 (2008).

5. Marshall, S. T. et al. Controlled selectivity for palladium catalysts using selfassembled monolayers. Nat. Mater. 9, 853-858 (2010).

6. Zhai, P. et al. Highly tunable selectivity for syngas-derived alkenes over zinc and sodium-modulated $\mathrm{Fe}_{5} \mathrm{C}_{2}$ catalyst. Angew. Chem. Int. Ed. Engl. 55, 9902-9907 (2016).

7. Weckhuysen, B. M. Determining the active site in a catalytic process: Operando spectroscopy is more than a buzzword. Phys. Chem. Chem. Phys. 5, 4351-4360 (2003).

8. Tanabe, T. et al. Operando X-ray absorption spectroscopy study of $\mathrm{Pt} / \gamma-\mathrm{Al}_{2} \mathrm{O}_{3}$ during the total oxidation of $\mathrm{C}_{3} \mathrm{H}_{6}$. Top. Catal. 52, 1433-1439 (2009).

9. Zhou, Y. et al. Dopant-induced electron localization drives $\mathrm{CO}_{2}$ reduction to $\mathrm{C}_{2}$ hydrocarbons. Nat. Chem. 10, 974-980 (2018).

10. Greiner, M. T. et al. Free-atom-like d states in single-atom alloy catalysts. Nat Chem. 10, 1008-1015 (2018).

11. Briggs, N. M. et al. Identification of active sites on supported metal catalysts with carbon nanotube hydrogen highways. Nat. Commun. 9, 3827 (2018).

12. Yang, H. et al. A highly stable copper-based catalyst for clarifying the catalytic roles of $\mathrm{Cu}^{0}$ and $\mathrm{Cu}^{+}$species in methanol dehydrogenation. Angew. Chem. Int. Ed. Engl. 57, 1836-1840 (2018).

13. Wen, G., Wu, S., Li, B., Dai, C. \& Su, D. S. Active sites and mechanisms for direct oxidation of benzene to phenol over carbon catalysts. Angew. Chem. Int. Ed. Engl. 54, 4105-4109 (2015).

14. Yang, Y. et al. In situ X-ray absorption spectroscopy of a synergistic Co-Mn oxide catalyst for the oxygen reduction reaction. J. Am. Chem. Soc. 141, 1463-1466 (2019).

15. Conner, W. C. \& Falconer, J. L. Spillover in heterogeneous catalysis. Chem. Rev. 95, 759-788 (1995).

16. Prins, R. Hydrogen spillover. Facts and fiction. Chem. Rev. 112, 2714-2738 (2012).

17. Zhang, J. et al. Origin of synergistic effects in bicomponent cobalt oxide-platinum catalysts for selective hydrogenation reaction. Nat. Commun. 10, 4166 (2019) 
18. Ali, L. I., Ali, A. G. A., Aboul-Fotouh, S. M. \& Aboul-Gheit, A. K. Dehydrogenation of cyclohexane on catalysts containing noble metals and their combinations with platinum on alumina support. Appl. Catal. A 177, 99-110 (1999).

19. Zhang, A., Nakamura, I., Aimoto, K. \& Fujimoto, K. Isomerization of npentane and other light hydrocarbons on hybrid catalyst. Effect of hydrogen spillover. Ind. Eng. Chem. Res. 34, 1074-1080 (1995)

20. Wang, $H$. et al. Platinum-modulated cobalt nanocatalysts for low-temperature aqueous-phase Fischer-Tropsch synthesis. J. Am. Chem. Soc. 135, 4149-4158 (2013).

21. Yang, G. et al. Design and modification of zeolite capsule catalyst, a confined reaction field, and its application in one-step isoparaffin synthesis from syngas. Energy Fuels 22, 1463-1468 (2008).

22. Park, J. et al. Investigation of support effect in atomically dispersed Pt on $\mathrm{WO}_{3-x}$ for high utilization of $\mathrm{Pt}$ in hydrogen evolution reaction. Angew. Chem. Int. Ed. Engl. 58, 16038-16042 (2019)

23. Yao, Y. \& Goodman, D. W. Direct evidence of hydrogen spillover from Ni to $\mathrm{Cu}$ on Ni-Cu bimetallic catalysts. J. Mol. Catal. A: Chem. 383, 239-242 (2014).

24. Phaahlamohlaka, T. N. et al. Effects of Co and Ru intimacy in Fischer-Tropsch catalysts using hollow carbon sphere supports: assessment of the hydrogen spillover processes. ACS Catal. 7, 1568-1578 (2017).

25. Karim, W. et al. Catalyst support effects on hydrogen spillover. Nature 541, 68-71 (2017)

26. Zhan, G. \& Zeng, H. C. Hydrogen spillover through Matryoshka-type

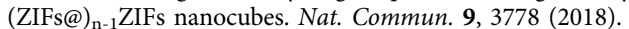

27. Nabaho, D., Niemantsverdriet, J. W., Claeys, M. \& van Steen, E. Hydrogen spillover in the Fischer-Tropsch synthesis: an analysis of platinum as a promoter for cobalt-alumina catalysts. Catal. Today 261, 17-27 (2016).

28. Beaumont, S. K. et al. Combining in Situ NEXAFS spectroscopy and $\mathrm{CO}_{2}$ methanation kinetics to study $\mathrm{Pt}$ and Co nanoparticle catalysts reveals key insights into the role of platinum in promoted cobalt catalysis. J. Am. Chem. Soc. 136, 9898-9901 (2014).

29. Aitbekova, A. et al. Engineering of ruthenium-iron oxide colloidal heterostructures: improved yields in $\mathrm{CO}_{2}$ hydrogenation to hydrocarbons. Angew. Chem. Int. Ed. Engl. 58, 17451-17457 (2019).

30. Witoon, T. et al. Enhanced activity, selectivity and stability of a $\mathrm{CuO}-\mathrm{ZnO}-\mathrm{ZrO}_{2}$ catalyst by adding graphene oxide for $\mathrm{CO}_{2}$ hydrogenation to methanol. Chem. Eng. J. 334, 1781-1791 (2018).

31. Kyriakou, G. et al. Isolated metal atom geometries as a strategy for selective heterogeneous hydrogenations. Science 335, 1209-1212 (2012).

32. Wrasman, C. J. et al. Synthesis of colloidal Pd/Au dilute alloy nanocrystals and their potential for selective catalytic oxidations. J. Am. Chem. Soc. 140, 12930-12939 (2018)

33. Wang, S. et al. Activation and spillover of hydrogen on sub-1 nm palladium nanoclusters confined within sodalite zeolite for the semi-hydrogenation of alkynes. Angew. Chem. Int. Ed. Engl. 58, 7668-7672 (2019).

34. Yook, S., Shin, H., Kim, H. \& Choi, M. Selective dissociation of dihydrogen over dioxygen on a hindered platinum surface for the direct synthesis of hydrogen peroxide. ChemCatChem 6, 2836-2842 (2014).

35. Taniya, K., Jinno, H., Kishida, M., Ichihashi, Y. \& Nishiyama, S. Preparation of Sn-modified silica-coated Pt catalysts: a new PtSn bimetallic model catalyst for selective hydrogenation of crotonaldehyde. J. Catal. 288, 84-91 (2012).

36. George, S. M. Atomic layer deposition: an overview. Chem. Rev. 110, 111-131 (2010).

37. Gao, Z. \& Qin, Y. Design and properties of confined nanocatalysts by atomic layer deposition. Acc. Chem. Res. 50, 2309-2316 (2017).

38. Gao, Z. et al. Multiply confined nickel nanocatalysts produced by atomic layer deposition for hydrogenation reactions. Angew. Chem. Int. Ed. Engl. 54, 9006-9010 (2015).

39. Biesinger, M. C. et al. Resolving surface chemical states in XPS analysis of first row transition metals, oxides and hydroxides: $\mathrm{Cr}, \mathrm{Mn}, \mathrm{Fe}, \mathrm{Co}$ and $\mathrm{Ni}$. Appl. Surf. Sci. 257, 2717-2730 (2011).

40. Vaz, C. A. F., Prabhakaran, D., Altman, E. I. \& Henrich, V. E. Experimental study of the interfacial cobalt oxide in $\mathrm{Co}_{3} \mathrm{O}_{4} / \alpha-\mathrm{Al}_{2} \mathrm{O}_{3}(0001)$ epitaxial films. Phys. Rev. B 80, 155457 (2009).

41. Banerjee, D. et al. Convenient and mild epoxidation of alkenes using heterogeneous cobalt oxide catalysts. Angew. Chem. Int. Ed. Engl. 53, 4359-4363 (2014).

42. Tian, $\mathrm{S}$. et al. Carbon nitride supported $\mathrm{Fe}_{2}$ cluster catalysts with superior performance for alkene epoxidation. Nat. Commun. 9, 2353 (2018).

43. Im, J., Shin, H., Jang, H., Kim, H. \& Choi, M. Maximizing the catalytic function of hydrogen spillover in platinum-encapsulated aluminosilicates with controlled nanostructures. Nat. Commun. 5, 3370 (2014).

44. Wang, C. et al. Product selectivity controlled by nanoporous environments in zeolite crystals enveloping rhodium nanoparticle catalysts for $\mathrm{CO}_{2}$ hydrogenation. J. Am. Chem. Soc. 141, 8482-8488 (2019).
45. Nabaho, D., Niemantsverdriet, J. W., Claeys, M. \& van Steen, E. Hydrogen spillover in the Fischer-Tropsch synthesis: an analysis of gold as a promoter for cobalt-alumina catalysts. Catal. Today 275, 27-34 (2016).

46. Beaumont, S. K., Alayoglu, S., Specht, C., Kruse, N. \& Somorjai, G. A. A nanoscale demonstration of hydrogen atom spillover and surface diffusion across silica using the kinetics of $\mathrm{CO}_{2}$ methanation catalyzed on spatially separate Pt and Co nanoparticles. Nano Lett. 14, 4792-4796 (2014).

47. Abbas, I., Kim, H., Shin, C. H., Yoon, S. \& Jung, K.-D. Differences in bifunctionality of $\mathrm{ZnO}$ and $\mathrm{ZrO}_{2}$ in $\mathrm{Cu} / \mathrm{ZnO} / \mathrm{ZrO}_{2} / \mathrm{Al}_{2} \mathrm{O}_{3}$ catalysts in hydrogenation of carbon oxides for methanol synthesis. Appl. Catal. B Environ. 258, 117971 (2019).

48. Spreafico, C., Karim, W., Ekinci, Y., van Bokhoven, J. A. \& VandeVondele, J. Hydrogen adsorption on nanosized platinum and dynamics of spillover onto alumina and titania. J. Phys. Chem. C 121, 17862-17872 (2017).

49. Choi, M., Yook, S. \& Kim, H. Hydrogen spillover in encapsulated metal catalysts: new opportunities for designing advanced hydroprocessing catalysts. Chem CatChem 7, 1048-1057 (2015).

50. Lu, J. et al. Coking-and sintering-resistant palladium catalysts achieved through atomic layer deposition. Science 335, 1205-1208 (2012).

51. Marimuthu, A., Zhang, J. \& Linic, S. Tuning selectivity in propylene epoxidation by plasmon mediated photo-switching of $\mathrm{Cu}$ oxidation state. Science 339, 1590-1593 (2013).

52. Greiner, M. T., Jones, T. E., Klyushin, A., Knop-Gericke, A. \& Schlögl, R. Ethylene epoxidation at the phase transition of copper oxides. J. Am. Chem. Soc. 139, 11825-11832 (2017).

53. Ozbek, M. O. \& van Santen, R. A. The mechanism of ethylene epoxidation catalysis. Catal. Lett. 143, 131-141 (2013)

54. Kokalj, A., Gava, P., De Gironcoli, S. \& Baroni, S. What determines the catalyst's selectivity in the ethylene epoxidation reaction. J. Catal. 254, 304-309 (2008).

55. Li, G., Wang, B. \& Resasco, D. E. Water-mediated heterogeneously catalyzed reactions. ACS Catal. 10, 1294-1309 (2020).

56. Rawat, K. S., Mahata, A. \& Pathak, B. Thermochemical and electrochemical $\mathrm{CO}_{2}$ reduction on octahedral $\mathrm{Cu}$ nanocluster: role of solvent towards product selectivity. J. Catal. 349, 118-127 (2017).

57. Merte, L. R. et al. Water-mediated proton hopping on an iron oxide surface. Science 336, 889-893 (2012).

\section{Acknowledgements}

We acknowledge the financial support from the National Natural Science Foundation of China (21773282, U1932131, U1832208, and 21673269), National Science Fund for Distinguished Young Scholars (21825204), the National Key R\&D Program of China (2017YFA0700101), Natural Science Foundation of Shanxi Province (201801D211011), Excellent Youth Scholars of State Key Laboratory of Coal Conversion (2016BWZ004), and Youth Innovation Promotion Association of the Chinese Academy of Sciences (2018208). We are grateful to all staff at the 1W1B beamline of the Beijing Synchrotron Radiation Facility, Institute of High Energy Physics, Chinese Academy of Sciences, and at BL14W1 beamline of the Shanghai Synchrotron Radiation Facility, Shanghai Institute of Applied Physics, Chinese Academy of Sciences.

\section{Author contributions}

Z.G. and Y.Q. conceived the idea and supervised the work. M.X. synthesized the catalysts and performed the activity tests. G.W., J.Y.M., and Z.J. helped to perform or provide the XAFS measurement. S.X., W.Y., and P.W. assisted in the synthesis and characterizations of the catalysts. P.Z., X.L., J.P.M., and J.X. provided valuable suggestion for the improvement of the work. M.X., Z.G., and Y.Q. wrote the manuscript. All authors contributed to the manuscript.

\section{Competing interests}

The authors declare no competing interests.

\section{Additional information}

Supplementary information is available for this paper at https://doi.org/10.1038/s41467020-18567-6.

Correspondence and requests for materials should be addressed to Z.G. or Y.Q.

Peer review information Nature Communications thanks Greiner and the other, anonymous, reviewer(s) for their contribution to the peer review of this work.

Reprints and permission information is available at http://www.nature.com/reprints

Publisher's note Springer Nature remains neutral with regard to jurisdictional claims in published maps and institutional affiliations. 
(c) (i) Open Access This article is licensed under a Creative Commons Attribution 4.0 International License, which permits use, sharing, adaptation, distribution and reproduction in any medium or format, as long as you give appropriate credit to the original author(s) and the source, provide a link to the Creative Commons license, and indicate if changes were made. The images or other third party material in this article are included in the article's Creative Commons license, unless indicated otherwise in a credit line to the material. If material is not included in the article's Creative Commons license and your intended use is not permitted by statutory regulation or exceeds the permitted use, you will need to obtain permission directly from the copyright holder. To view a copy of this license, visit http://creativecommons.org/ licenses/by/4.0/.

(C) The Author(s) 2020 